\title{
Investigation on the Reducibility of Agbaja Iron Ore Lumps
}

ISSN: 2576-8840

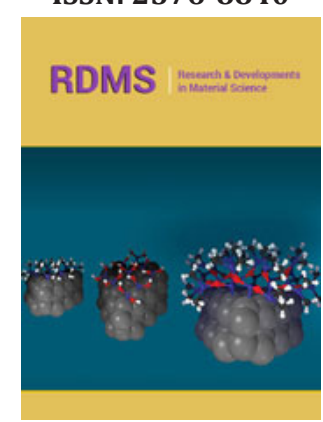

*Corresponding author: Ocheri C, Department of Metallurgical and Materials Engineering, University of Nigeria, Nsukka

Submission: 非 April 28, 2020

Published: 睑 May 11, 2020

Volume 13 - Issue 3

How to cite this article: Ocheri C, Njoku RE, Urama NA, Mbah CN. Investigation on the Reducibility of Agbaja Iron Ore Lumps. Res DevMaterialSci.13(3).RDMS.000811.2020. DOI: 10.31031/RDMS.2020.13.000811

Copyright@ Ocheri C, This article is distributed under the terms of the Creative Commons Attribution 4.0 International License, which permits unrestricted use and redistribution provided that the original author and source are credited.

\section{Ocheri C ${ }^{1 *}$, Njoku $\mathrm{RE}^{2}$, Urama $\mathrm{NA}^{2}$ and Mbah $\mathrm{CN}^{1}$}

${ }^{1}$ Department of Metallurgical and Materials Engineering, University of Nigeria, Nsukka

${ }^{2}$ Department of Metallurgical and Materials Engineering, Enugu State University of Science and Technology, Nigeria

\section{Abstract}

The investigation on the reducibility of Agbaja iron ore lumps were performed .The chemical compositions, morphology and structural analysis of the ore were examined. Various equipment such as Thermogravimetry (TG), Differential Thermal Analyzer (DTA), X-Ray Fluorescence (XRF), X-Ray Diffraction (XRD), Inverted Metallurgical Optical Microscopy and Scanning Electron Microscopy (SEM) with Energy Dispersive Spectroscopy (EDS). The reducibility experiments were performed where a muffle furnace was used as the heating device. The Agbaja iron ore lumps were taken inside six (6) stainless steel containers with diameter $60.75 \mathrm{~mm} \times 59.40 \mathrm{~mm}$ inside diameter with mouths tightly closed by air tight covers having out let for exit gases. Metallurgical coking coal obtained from the Ajaokuta Steel Company Limited was used as the reducing agent. The experiments were performed where the ore lumps were crushed to some sizes and heated in the furnace ranging from $800^{\circ} \mathrm{C}$ to $1000^{\circ} \mathrm{C}$ for heating periods with interval temperature was $40^{\circ} \mathrm{C}$. The temperature interval rate was put at $40^{\circ} \mathrm{C}$. The corresponding heating period was from 20 minutes to 120 minutes with interval time of 20 minutes.The highest corresponding values for each temperature and heating period was put in the following order. The heating temperature of $800^{\circ} \mathrm{C}$ for 120 minutes had corresponding values of $21.3 \%$ of reduction, at $840^{\circ} \mathrm{C}$ for 120 minutes heating period gave a corresponding value of $25.0 \%$ of reduction. The result obtained when the ore lump was heated at $880^{\circ} \mathrm{C}$ for 120 minutes gave a corresponding value of $26.7 \%$ of reduction, at $920^{\circ} \mathrm{C}$ for 120 minutes, the corresponding value was $27,1 \%$ of reduction. The other corresponding values when the ore samples were heated to $960^{\circ} \mathrm{C}$ and $1000^{\circ} \mathrm{C}$ for both 120 minutes gave $31.0 \%$ and $33.0 \%$ degree of reduction respectively. The reduced Agbaja iron ore lumps were further analyzed using the Scanning Electron Microscopy (SEM) with Energy Dispersive Spectroscopy (EDS) and obtained the results as indicated in this orders. The values of Fe content for Agbaja iron ore lump at $800^{\circ} \mathrm{C}$ for 120 minutes was $40.7 \mathrm{wt} \%$, at $920^{\circ} \mathrm{C}$ for 120 minutes, the Fe content value was $60.2 \mathrm{wt} \%$ and at $1000^{\circ} \mathrm{C}$ for 120 minutes, the Fe content was $56.2 \mathrm{wt} \%$.. These results showed that the Agbaja iron ore reduced more at $800^{\circ} \mathrm{C}$ for 120 minutes (40.7wt \%) followed by $1000^{\circ} \mathrm{C}$ for 120 minutes (56.2wt \%) and the least reduced heating period and time was when the iron ore samples was heated at $920^{\circ} \mathrm{C}$ for 120 minutes $(60.2 \mathrm{wt} \%)$.

Keywords: Reducibility; Agbaja; Iron ore; Lumps

\section{Introduction}

Table 1: Chemical composition and estimated reserve of some Nigerian iron ore.

\begin{tabular}{|c|c|c|c|c|c|c|c|c|c|c|}
\hline \multirow{2}{*}{$\begin{array}{c}\text { Iron ore } \\
\text { Deposit }\end{array}$} & $\mathbf{F e}$ & $\mathbf{S i O}_{2}$ & $\mathbf{A l}_{2} \mathbf{O}_{3}$ & $\mathbf{C a O}$ & $\mathbf{M g O}$ & $\mathbf{T i O}_{2}$ & $\mathbf{M n O}$ & $\mathbf{P}$ & $\mathbf{S}$ & $\begin{array}{c}\text { Indicated } \\
\text { Interred } \\
\text { Reserve } \\
\text { in MT }\end{array}$ \\
\hline Itakpe & 32.68 & 44.80 & 1.0 & 0.30 & 0.20 & 0.10 & 0.05 & 0.18 & 0.05 & $200+310$ \\
\hline Oshokoshoko & 34.45 & 51.07 & 9.67 & 0.15 & 0.18 & 0.61 & 0.08 & 0.02 & 0.007 & 1085 \\
\hline Ajabanoko & 37.22 & 46.50 & 3.39 & 0.21 & 0.15 & - & 0.01 & 0.10 & 0.03 & 2565 \\
\hline Agbaja & 47.80 & 10.89 & 9.60 & 0.72 & 0.38 & 0.37 & 0.14 & 0.08 & 0.12 & 9621250 \\
\hline KotonKarfi & 48.15 & 5.13 & 6.70 & 0.45 & 0.07 & 0.24 & 0.56 & 2.14 & 0.04 & 428,850 \\
\hline BassaNge & 46.90 & 8.28 & 10.87 & 0.46 & 0.46 & 0.26 & 0.13 & 1.45 & 0.05 & 825450 \\
\hline Muro & 31.60 & 40.00 & 0.40 & 0.50 & 2.10 & 0.20 & 0.10 & 0.10 & 0.10 & 3.8 \\
\hline
\end{tabular}

Source: Asuquo and Nebo, 1994, Uwadiale and Nwoke, 1995 
It should be noted that Iron ore deposit was discovered in Nigeria as far back as 1904, since then several deposits have been discovered. Table 1 shows the Chemical Compositions and Estimated Reserve of some Nigerian Iron ores. The deposits are hematite, magnetite, goethite or siderite - goethite grades. Effective harnessing of the estimated reserve deposits which runs to over 3.1 billion metric will generate employment opportunities, wealth creation, revenue generation and foreign exchange earnings as these will further improve technological base i.e. in agricultural sector, military defense and provision of infrastructures and reviving of the moribund iron and steel industries across the nation.

\section{Reducibility}

This is a name for the velocity of iron oxide transformation to metal by effect of gas reduction, or also a time needed for a complete iron oxide reduction. The value of the reduction rate is the metallic charge weight loss per a time unit. The weight loss caused by the charge oxygen transformation into gas.

$$
R_{1}=\frac{A_{0}}{\sum_{0}} x 100(\%)
$$

Where - degree of (indirect) gas reduction

$\Sigma_{0}$ - Total mass weight of oxygen bound to iron [g]

$A_{0}$ - Difference in mass weight of oxygen in ore during gas reduction $[\mathrm{g}]$

The reducibility has a lot of influence on the blast furnace operation which is highly important; it can be used for a fuel consumption determination and a selection of proper lumpiness. The reducibility value changes in particular by hot treatment (sintering). The charge porosity influences the reducibility, too. The higher porosity of the charge, the larger reaction surface and the faster gas reduction. The ISO - R ISO950 standard is the main parameter when considering the reduction velocity $\mathrm{v}_{40}$. The velocity of oxygen degradation in percentage $\cdot \mathrm{min}^{-1}$ at $40 \%$ reduction degree are determined.

$$
v_{40}=\left|\frac{d R}{d t}\right|_{\left(\frac{O}{F_{e}}=0,9\right)=\frac{33,6}{t_{60}-t_{30}}},\left(\% \mathrm{~min}^{-1}\right)
$$

Where: $\mathrm{t}_{30}$ - time to reach $30 \% \mathrm{R}$ (min)

$\mathrm{t}_{60}$ - time to reach $60 \% \mathrm{R}(\mathrm{min})$

The constant $=33$

\section{Research Methodology}

\section{Materials}

Agbaja iron ores: The Agbaja iron ore lumps are in sizes or in fines. Production/availability of lumps is limited by virtue of the natural occurrence and because of generation of lot of fines during crushing of large lumps present in the run-off -mines (ROM). Iron ore with very low-grade iron ore are not suitable for operating the metallurgical plants. The very low -grade ores are upgraded to increase the iron content and reduce the gangue content. Beneficiation is a process adopted to upgrade the iron ore. Concentration is the process that involves the upgrading of ore to higher iron content for metallurgical processes. Iron ore is being beneficiated all round the world to meet the quality requirement of Iron and Steel industries. However, each source of iron ore has its own peculiar mineralogical characteristics and requires the specific beneficiation and metallurgical treatment to get the best product out of it. The choice of the beneficiation treatment depends on the nature of the gangue present and its association with the ore structure. The techniques for processing the ores are washing, jigging, magnetic separation; advanced gravity separation and flotation enhance the quality of the iron ore. Due to the high density of hematite relative to silicates, beneficiation usually involves combination of crushing and milling as well as heavy liquid separation. The finely crushed ores passes over the bath of solutions containing bentonite or other agent, which increases the density of the solution. The unwanted elements are removed from the solution as the silicate mineral fragments float. The hematite sinks due to calibration solution density.

The Agbaja Iron ore is an acidic pisolitic/ oolitic ore consisting of goethite, magnetic and major amounts of aluminious and siliceous materials [1]. It cannot be used directly in the Blast Furnace process or other reduction process without further treatment e.g. pelletization or briquetting. The ore is a lean ore and sedimentary origin [1]. It is therefore necessary to harness the opportunities created to work on the ore in order to add economic value to our national economy. The ore is also known to be oolittitic in nature, limonite that occur in mannmilated or stalactite forms having fibrous structure resembling hematite [1]. The Agbaja Iron ores are made of brown compacted fine-grained materials, which consist of extremely lager particles, and friable in nature. Agbaja iron ore is strongly magnetic [2]. The ore particles were further processed by crushing them for specific experimental procedure. The Agbaja iron ore sample were compacted ground fine particles, which significantly exhibits the characteristics of being friable and magnetically strong. The picture below shows the iron ore as being sourced at the Agbaja plateau in Kogi State (Figure 1).

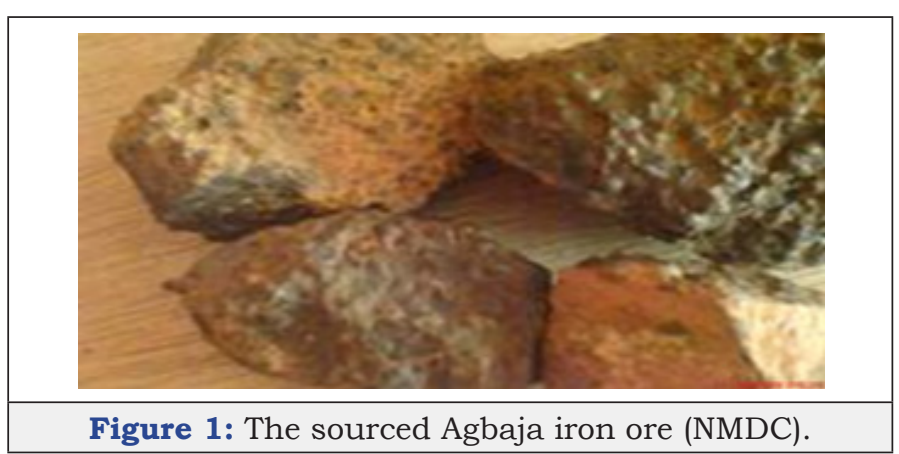

\section{Chemical analysis agbaja iron ore}

Table 2 shows the results of the chemical compositions of Agbaja iron ore lumps. These chemical compositions were determined using X- Ray Fluorescence (XRF) methods. The experiments were performed at the laboratory of Tshwane University of Technology, South Africa on (2019-1-16 17:53) 
Table 2: The chemical compositions of Agbaja iron ore using XRF Method.

\begin{tabular}{|c|c|c|}
\hline Component & Unit & Result \\
\hline $\mathrm{Na}_{2} \mathrm{O}$ & mass $\%$ & 0.1183 \\
\hline $\mathrm{MgO}$ & mass $\%$ & 0.2464 \\
\hline $\mathrm{Al}_{2} \mathrm{O}_{3}$ & mass $\%$ & 6.047 \\
\hline $\mathrm{SiO}_{2}$ & mass $\%$ & 25.2321 \\
\hline $\mathrm{P}_{2} \mathrm{O}_{5}$ & mass $\%$ & 0.0227 \\
\hline $\mathrm{SO}_{3}$ & mass $\%$ & 0.1899 \\
\hline $\mathrm{Cl}$ & mass $\%$ & 0.0955 \\
\hline $\mathrm{K}_{2} \mathrm{O}$ & mass $\%$ & 0.4294 \\
\hline $\mathrm{CaO}$ & mass $\%$ & 0.4284 \\
\hline $\mathrm{TiO}_{2}$ & mass $\%$ & 0.8505 \\
\hline $\mathrm{Cr}_{2} \mathrm{O}_{3}$ & mass $\%$ & 0.0895 \\
\hline $\mathrm{MnO}$ & mass $\%$ & 0.4983 \\
\hline $\mathrm{Fe}_{2} \mathrm{O}_{3}$ & mass $\%$ & 43.7579 \\
\hline $\mathrm{NiO}$ & mass $\%$ & 0.053 \\
\hline $\mathrm{CuO}$ & $\operatorname{mass} \%$ & 0.0107 \\
\hline $\mathrm{ZnO}$ & mass $\%$ & 0.0555 \\
\hline $\mathrm{ZrO}_{2}$ & mass $\%$ & 0.0206 \\
\hline $\mathrm{P}_{2} \mathrm{O}_{5}$ & mass $\%$ trace & trace \\
\hline
\end{tabular}

\section{X-Ray Diffraction (XRD) on Agbaja iron ore}

(Figure 2; Table 3)

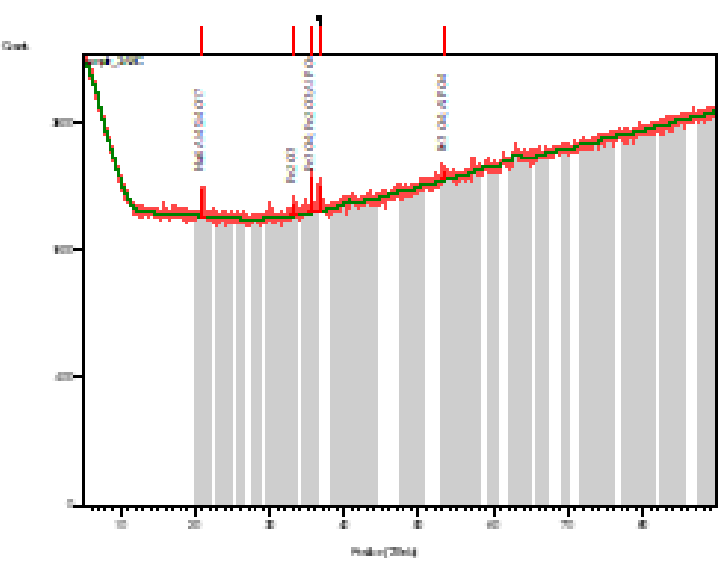

Figure 2: X-ray diffraction on Agbaja Iron Ore.

Table 3: Identified patterns list: Agbaja iron ore.

\begin{tabular}{|c|c|c|c|c|c|c|}
\hline Visible & $\begin{array}{c}\text { Ref. } \\
\text { Code }\end{array}$ & Score & $\begin{array}{c}\text { Compound } \\
\text { Name }\end{array}$ & $\begin{array}{c}\text { Displacement } \\
{\left[{ }^{\circ} \text { 2Th.] }\right.}\end{array}$ & $\begin{array}{c}\text { Scale } \\
\text { Factor }\end{array}$ & $\begin{array}{c}\text { Chemical } \\
\text { Formula }\end{array}$ \\
\hline$*$ & $\begin{array}{c}03- \\
0863\end{array}$ & 40 & Magnetite & 0 & 0.57 & Fe304 \\
\hline$*$ & $\begin{array}{c}76- \\
2385\end{array}$ & 35 & $\begin{array}{c}\text { Sodium } \\
\text { Aluminum } \\
\text { Silicate }\end{array}$ & 0 & 0.35 & $\begin{array}{c}\text { Na6 } \\
\text { Al4Si4017 }\end{array}$ \\
\hline$*$ & $\begin{array}{c}86- \\
0550\end{array}$ & 28 & $\begin{array}{c}\text { Hematite, } \\
\text { syn }\end{array}$ & 0 & 0.13 & Fe203 \\
\hline$*$ & $\begin{array}{c}48- \\
0652\end{array}$ & 9 & $\begin{array}{c}\text { Aluminum } \\
\text { Phosphate }\end{array}$ & 0 & 0.1 & AlP04 \\
\hline
\end{tabular}

\section{METALLURGICAL COKING COAL FROM AJAOKUTA STEEL COMPANY LIMITED}

Some quantity of Metallurgical Coking Coal was obtained from the Ajaokuta Steel Company Limited, The coal were crushed into sizes which were then used in the experiments as reducing agent. Table 4 shows the chemical compositions of the coal has been analysed by the vendor before inporting them to the Steel Company (Figure 3 \& 4).

Table 4: Chemical analysis of metallurgical coking coal.

\begin{tabular}{|c|c|c|}
\hline S/No & Chemical Compositions & Percentage (\%) \\
\hline 1 & Fixed Carbon & 85 \\
\hline 2 & Volatile Matter & 2.95 \\
\hline 3 & Ash Content & 9.5 \\
\hline 4 & Moisture & 2 \\
\hline 5 & Sulphur & 0.5 \\
\hline 6 & Phosphorus & 0.05 \\
\hline
\end{tabular}

Source: Ajaokuta Steel Company Limited, Ajaokuta

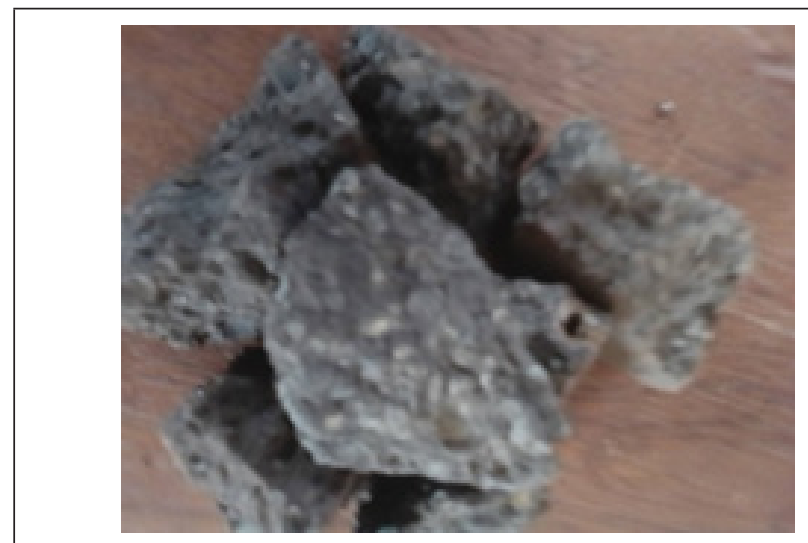

Figure 3: The metallurgical coking coal before they were used as reducing agent.

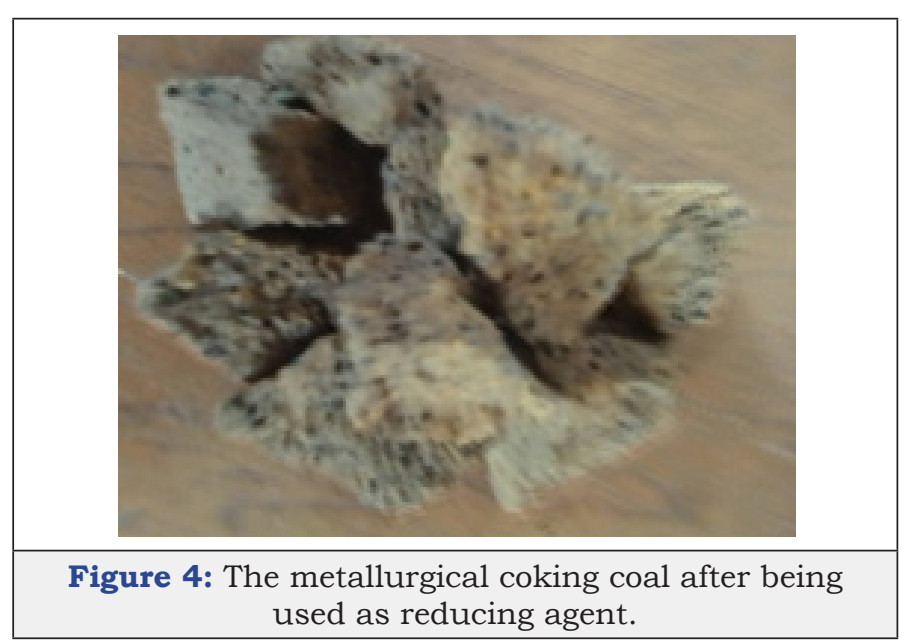

\section{Equipment and methods}

The following equipment were used for the preparation of the Agbaja iron ore lump samples. The research works were performed 
at Laboratories in the Department of Metallurgical and Materials Engineering and Laboratories at the Nigerian Liquefied Natural Gas (NLNG) in the Department of the Metallurgical and Materials Engineering of the University of Nigeria (UNN), Nsukka, Enugu State and the Laboratories of Extractive Metallurgy at Tshwane University of Technology, South Africa.

(a) Electronic digital weighing balance: The electronic digital weighing balance with model name C\&G GmbH Gielerister 6569 (41460) Neuss, Germany was used for weighing of the iron ore lumps at the laboratory of the Department of Metallurgical and Materials Engineering, University of Nigeria, Nsukka.

(b) Sample handler: The Agbaja Iron Ore lumps were carefully handled in order to avoid breakage during handling.

(c) Muffle furnace: A Muffle furnace was used for the heating of the Agbaja iron ores lumps.

(d) The laboratory dry oven: The Laboratory Dry Oven with model number DHG 9101 was used for heating of the samples at low temperature particularly with respect to determining the moisture contents of the iron ore lump samples [3].

(e) Inverted metallurgical microscope: The inverted metallurgical microscope with model name XJL-17 was used for the examination of the microstructures of the iron ore lump samples before and after the reducibility Tests. The equipment is also located at the laboratory of the Department of Metallurgical and Materials Engineering situated at the Nigerian Liquefied Natural Gas (NLNG) building, University of Nigeria, Nsukka.

\section{Methods}

The Iron ore lumps obtained consist of the chemical compositions given in Tables 2 (XRF). The Agbaja Iron ore lumps contain some amount of phosphorus. The morphologies of the ores were determined using the X-Ray Diffraction methods as shown in Figure 2.

\section{Experimental procedure of reducibility}

Reducibility is a summary of raw materials properties, which determines the rate of conversion of iron oxides to metals by treatment with reductant. A measure of reducibility is represented by a weight loss of ore samples per time unit caused by transition of oxygen into gas.

\section{Procedure for reduction studies}

a) The Agbaja Iron ore lumps were used for these experiments, while a metallurgical coking coal obtained from the Ajaokuta Steel Company Limited was also used as reductant (reducing agent).

b) The collected iron ores lumps were crushed in $15-20 \mathrm{~mm}$ sizes.

c) The collected Metallurgical coking coal was crushed to -5+ 15 size.

d) The chemical composition of the metallurgical coking coal is shown in Table 4. e) The crushed iron ore lumps were dried in the laboratory dry oven with a view to eliminating moisture content that was present in the ores as they were subjected to a temperature of $120^{\circ} \mathrm{C}$.

f) The crushed iron ore lumps were taken inside six (6) stainless steel containers (size: $60.75 \mathrm{~mm}$ height $\times 59.40 \mathrm{~mm}$ inside diameter) with mouths tightly closed by air tight covers having out let for exit gases. Then the lumps were surrounded with the metallurgical coking coals, which serves as reducing agent in the experiments at various period and time.

g) The crushed iron ore lumps were properly placed at the centre of the solid packed bed. These were done with a view to ensuring that the iron ore lumps inside the packed were surrounded.

h) The experimental procedures were strictly followed .The muffle furnace was used to heat up the iron ore lump samples to the required temperatures of $800{ }^{\circ} \mathrm{C}, 840{ }^{\circ} \mathrm{C}, 860$ ${ }^{\circ} \mathrm{C}, 880{ }^{\circ} \mathrm{C}, 920^{\circ} \mathrm{C}, 960{ }^{\circ} \mathrm{C}$ and $1000{ }^{\circ} \mathrm{C}$, at $8{ }^{\circ} \mathrm{C}$ per minutes rate. The samples were allowed to soak at various temperatures as indicated above by varying the soaking period in the range of 20-120 minutes at inverval of 20 minutes.

i) The experimental process was performed to determine the reducibility at the stipulated temperatures. Each of the containers was properly labelled for specific experiments. The samples were brought out from the muffle furnace at designated interval of 20 minutes up to 40 minutes residence, and the same processes were performed for all the rest samples at an interval of 20 minutes up to 120 minutes of residence in the furnace. The containers containing the samples were brought out from the muffle furnace and were allowed to cool at the room temperature in the normal atmospheric air. The weight losses analyses of the iron ore lumps were determined and recorded. The degrees of reduction (\%) of the lumps were calculated by using the following formula.

Degree of Reduction $=\frac{\text { Weight Loss }}{\text { Total weight of removable oxygen in Iron oxide }} \times 100 \%$

\section{Microscope Examination}

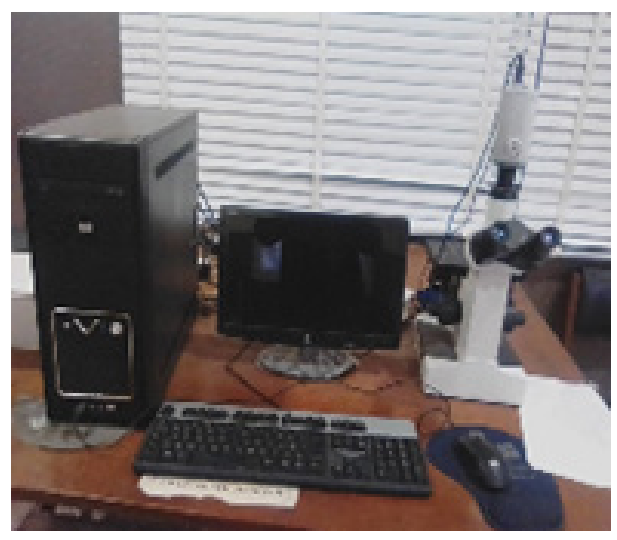

Figure 5: The inverted metallurgical microscope used for the determination of the samples microstructures. 
The inverted metallurgical microscope was used to examine the iron ore lumps as shown in Figure 5. Some important distinct phases were identified in the Agbaja iron ore lumps with some quality like texture with characteristic indicating that it contains pisolitic structure on the surface as indicated in Figure 6. The iron ore shows concentrated materials in the pisolite nature while the matrix present consists of major impurities (Figure 7-12).
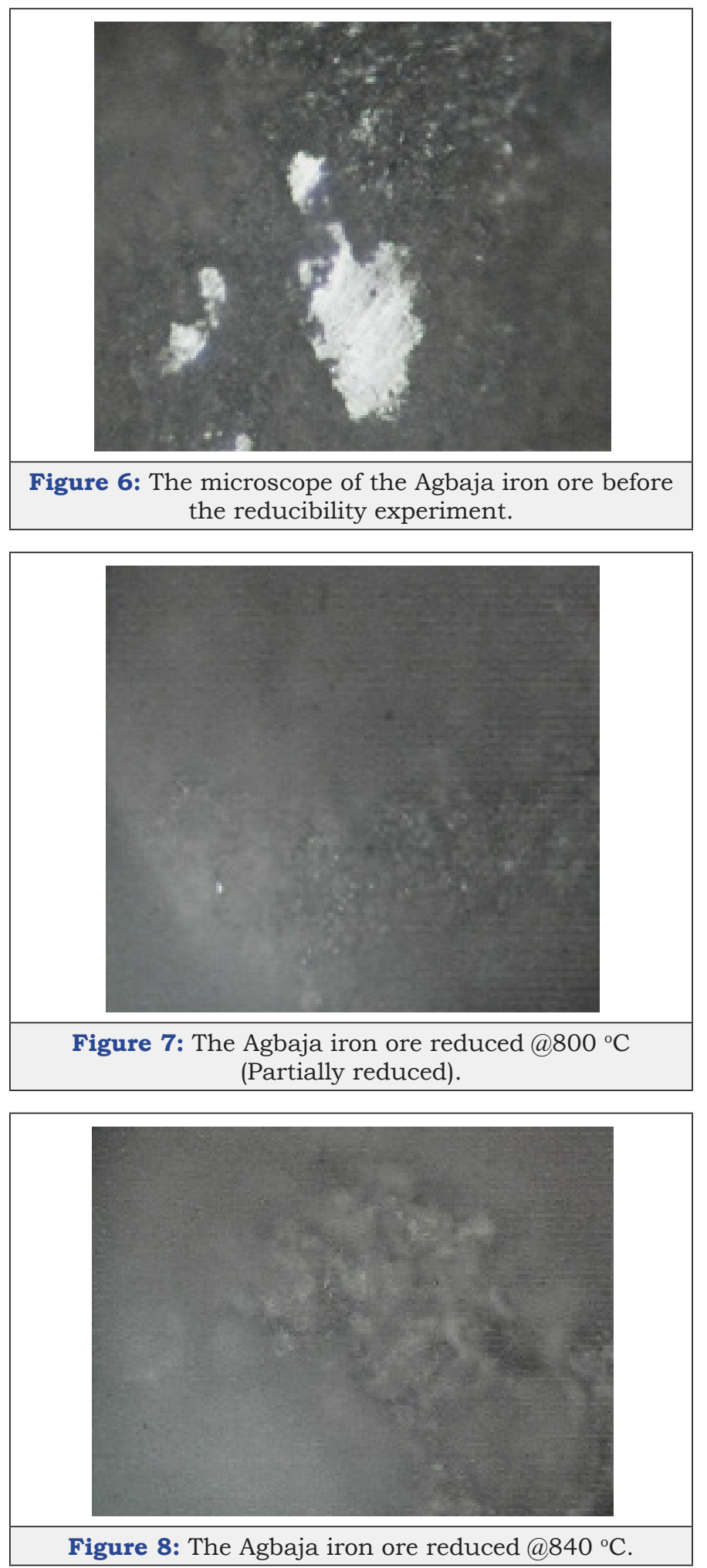
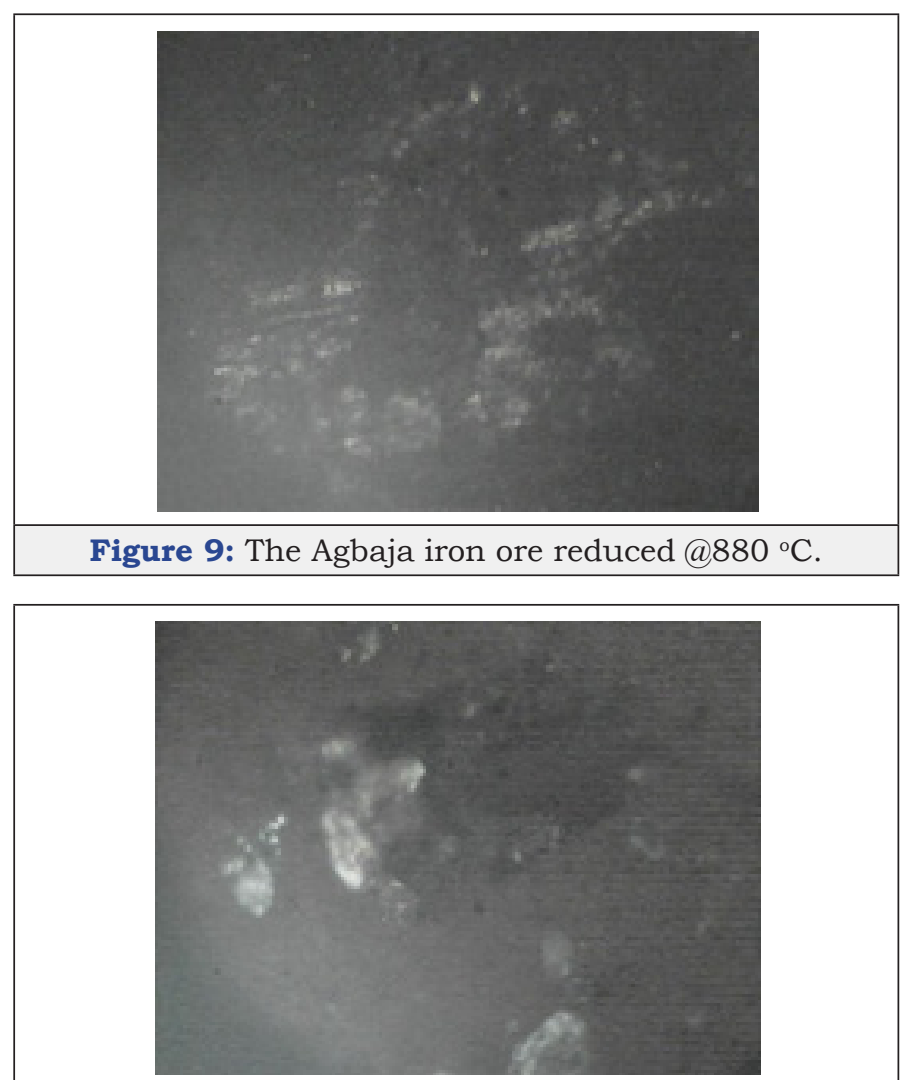

Figure 10: The Agbaja iron ore reduced @ $920{ }^{\circ} \mathrm{C}$.

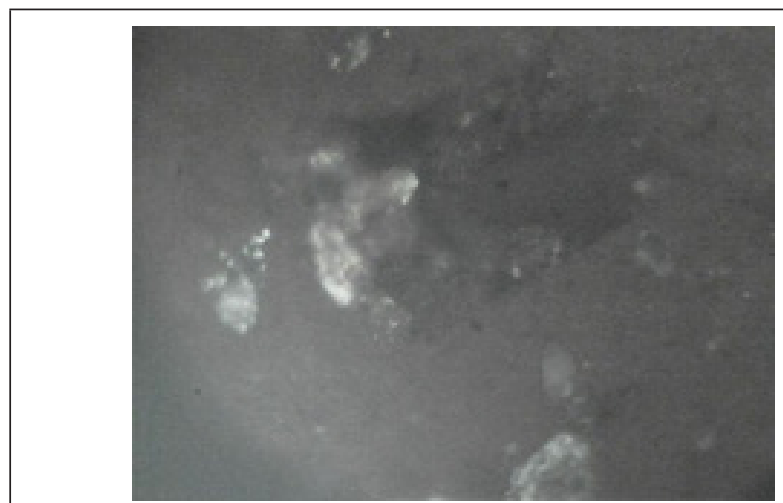

Figure 11: The Agbaja iIron ore @ $960{ }^{\circ} \mathrm{C}$ (Partially reduced).

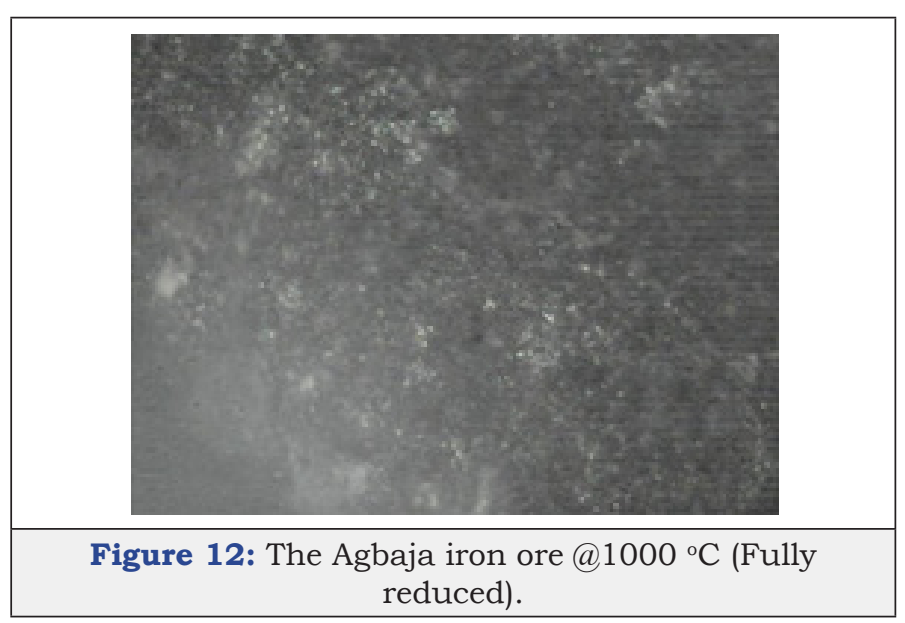




\section{Thermo Gravimetric Analysis (TGA) of Agbaja iron ore}

The blue line colour runs on $30^{\circ} \mathrm{C}$ got to $200^{\circ} \mathrm{C}$ and moved upwards, it got to the peak value of Deriv. weight $(\% \mathrm{C})$ at 0.13 with the corresponding temperature value at $300^{\circ} \mathrm{C}$. This value declined and continued at a steady movement and dovetailed at 0.00 Deriv. weight $(\% \mathrm{C})$. While the light green line started from 100 weight (\%) and continue to decline and dovetailed at 88.2 (weight $\%$ ) with corresponding value at $1000^{\circ} \mathrm{C}$. Figure 13 shows the Isothermal behavior of the thermal decomposition of the Agbaja iron ore.

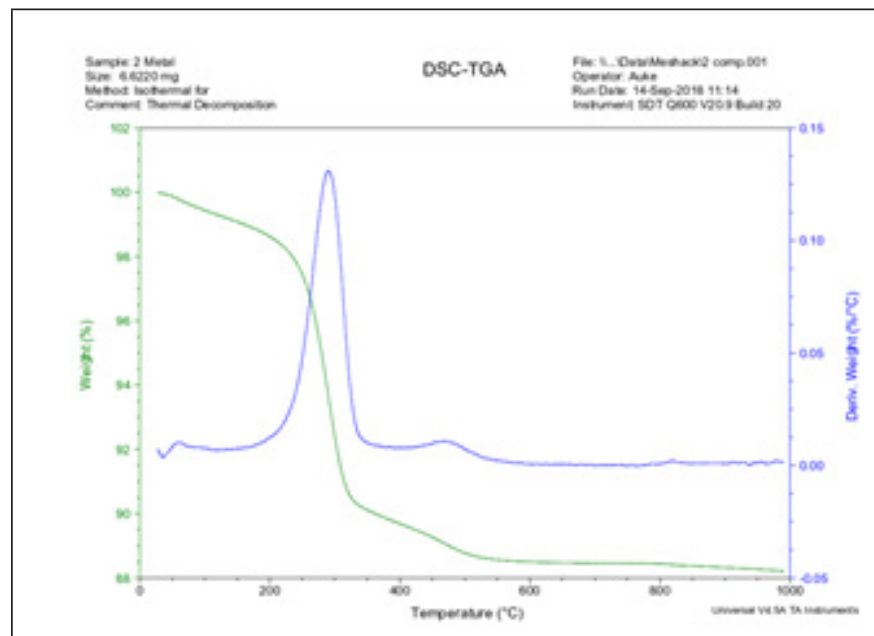

Figure 13: The thermo Gravimetry Analysis (TGA) performed on Agbaja iron ore.

Scanning Electron Microscope (SEM), Electron Image of the spectrum location 36 at $10 \mu \mathrm{m}$ and Energy-Dispersive Spectroscopy (EDS) of Agbaja iron ore

Figure 14 shows the sample been examined using Scanning Electron Microscopy (SEM) /Energy-Dispersive Spectroscopy (EDS) This reveal that there are fine and whitish structures found in the ore. The Figure 15 shows the three-spectrum locations that were taken in order to determine the concentration of ore. While Figure 16 shows spectrum 39 where the concentration of the elements are distributed with weight (\%) concentration ranging from $\mathrm{O}, \mathrm{Fe}, \mathrm{C}, \mathrm{Al}$, $\mathrm{Si}$ and $\mathrm{P}$ with their corresponding density values.

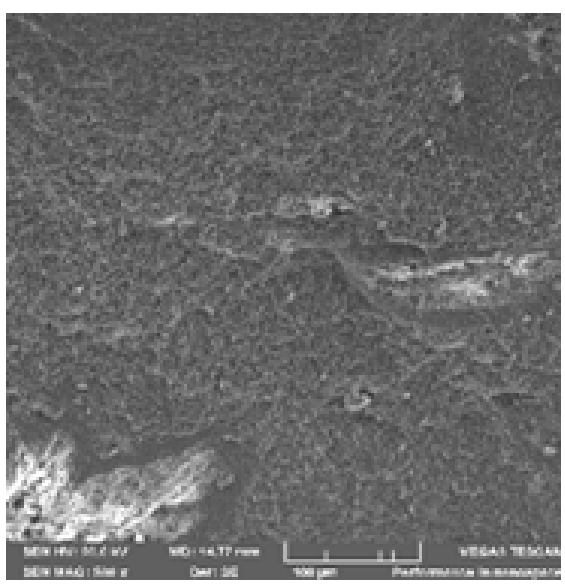

Figure 14: The Scanning Electron Microscopy (SEM) of the Agbaja iron ore at $100 \mu \mathrm{m}$.

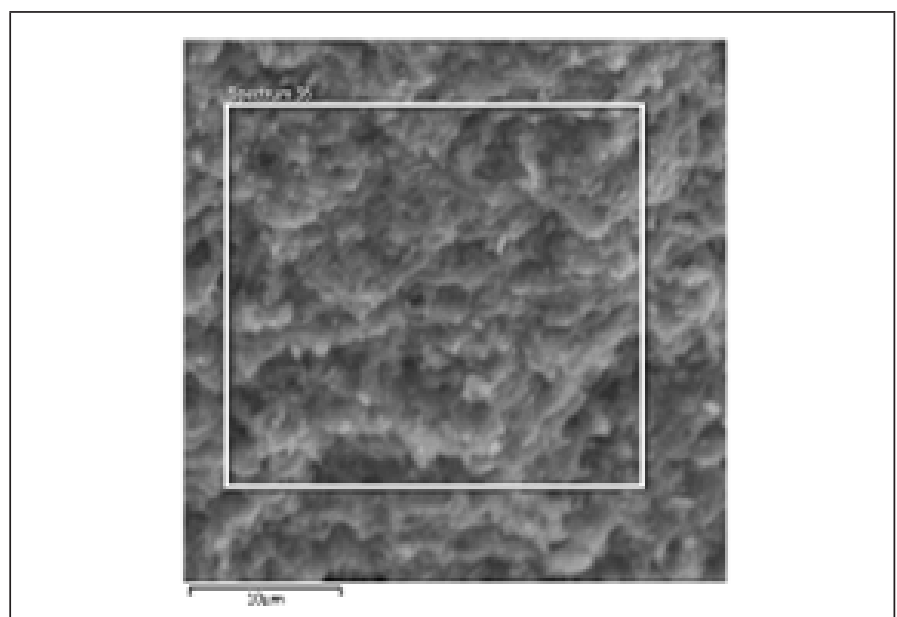

Figure 15: Electron image 12 of the spectrum location 36 at $10 \mu \mathrm{m}$.

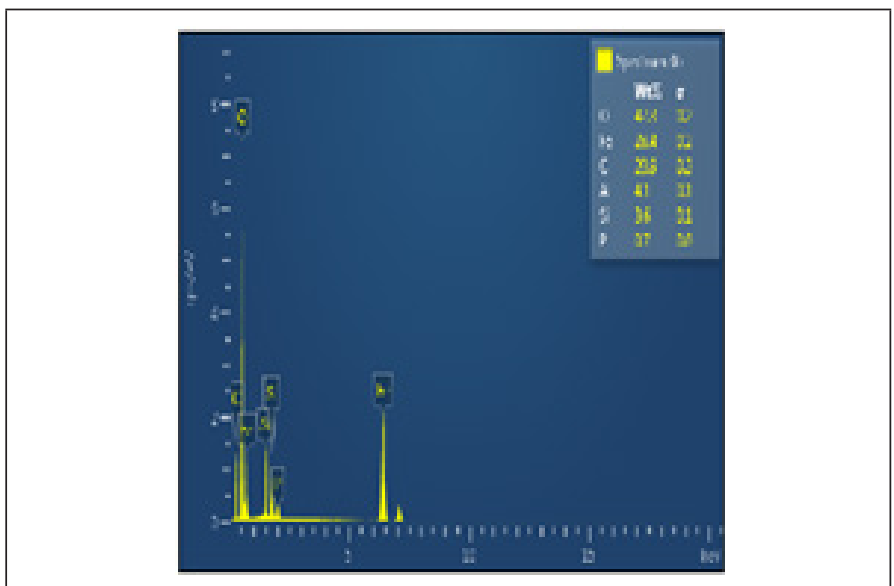

Figure 16: Energy dispersive spectroscopy.

Results and Discussion

\section{Results}

Table 5 \& Figure 17 show the degree of reduction(\%) as a function of furnace holding time for the reduction of Agbaja Iron ore lumps at temperature between $800^{\circ} \mathrm{C}-1000{ }^{\circ} \mathrm{C}$ and corresponding time from 20-120minutes.

Table 5: Agbaja iron ore lumps.

\begin{tabular}{|c|c|c|}
\hline Temperature & Time ( in min) & Degree of Reduction (\%) \\
\hline $800^{\circ} \mathrm{C}$ & 20 & 17.1 \\
\hline & 40 & 17.7 \\
\hline & 60 & 18.2 \\
\hline & 80 & 18.9 \\
\hline & 100 & 19.6 \\
\hline Temperature & 120 & 21.3 \\
\hline $840^{\circ} \mathrm{C}$ & Time ( in min) & Degree of reduction (\%) \\
\hline & 20 & 18 \\
\hline & 40 & 18.2 \\
\hline & 60 & 19.6 \\
\hline & 80 & 20.6 \\
\hline & 100 & 23.3 \\
\hline
\end{tabular}




\begin{tabular}{|c|c|c|}
\hline & 120 & 25.0 \\
\hline Temperature & Time ( in min) & Degree of reduction (\%) \\
\hline \multirow[t]{6}{*}{$880^{\circ} \mathrm{C}$} & 20 & 20.2 \\
\hline & 40 & 20.8 \\
\hline & 60 & 21.4 \\
\hline & 80 & 23.8 \\
\hline & 100 & 24.8 \\
\hline & 120 & 26.7 \\
\hline Temperature & Time (in min) & Degree of reduction (\%) \\
\hline \multirow[t]{6}{*}{$920^{\circ} \mathrm{C}$} & 20 & 22.8 \\
\hline & 40 & 23.2 \\
\hline & 60 & 23.6 \\
\hline & 80 & 24.1 \\
\hline & 100 & 25.9 \\
\hline & 120 & 27.1 \\
\hline Temperature & Time ( in min) & Degree of reduction (\%) \\
\hline \multirow[t]{6}{*}{$960^{\circ} \mathrm{C}$} & 20 & 23.4 \\
\hline & 40 & 23.8 \\
\hline & 60 & 24 \\
\hline & 80 & 24.7 \\
\hline & 100 & 26.1 \\
\hline & 120 & 31.0 \\
\hline Temperature & Time( in min) & Degree of reduction (\%) \\
\hline \multirow[t]{6}{*}{$1000^{\circ} \mathrm{C}$} & 20 & 24.2 \\
\hline & 40 & 25.1 \\
\hline & 60 & 25.8 \\
\hline & 80 & 26.5 \\
\hline & 100 & 29.5 \\
\hline & 120 & 33.0 \\
\hline
\end{tabular}

samples were fired in the muffle furnace from various temperatures range and corresponding times. The reducibility experiments were performed using the obtained metallurgical coking coal from the Ajaokuta Steel Company Limited, Ajaokuta in Kogi State as reducing agent. The iron ore lumps were subjected under identical slow heating temperature where the heating rate was maintained at 8 ${ }^{\circ} \mathrm{C} \mathrm{min}^{-1}$.

The samples were heated up to various temperatures ranging from $800{ }^{\circ} \mathrm{C}-1000{ }^{\circ} \mathrm{C}$ and the samples were allowed to soak for period of time ranging from 20 minutes to 120 minutes.

The corresponding values were collected and recorded and these values obtained were used to plot graphs as function of furnace holding time for the reduction (\%) of Agbaja Iron ore lumps at temperature between $800{ }^{\circ} \mathrm{C}-1000{ }^{\circ} \mathrm{C}$. The results obtained from the experiments showed that there was some degree of reduction (\%) in the iron ore lumps of the samples.

The Agbaja iron ore lumps are also shown on Figure 17-29 after the reducibility tests at various temperature and period of times. Some samples with the highest heating time were taken for further analyses which were the Scanning Eclectron Microscopy (SEM) with EDS.

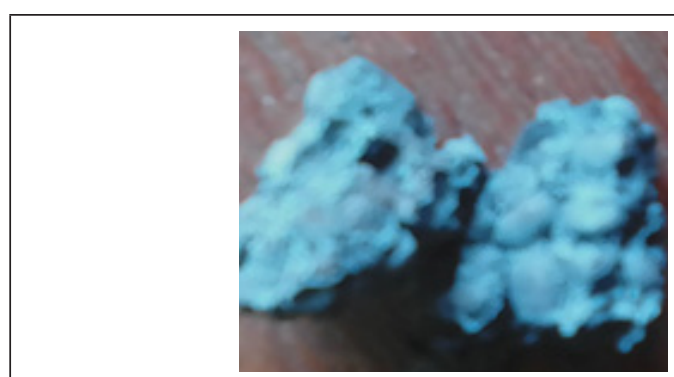

Figure 18: shows the reduced Agbaja iron ore $@ 960{ }^{\circ} \mathrm{C}$

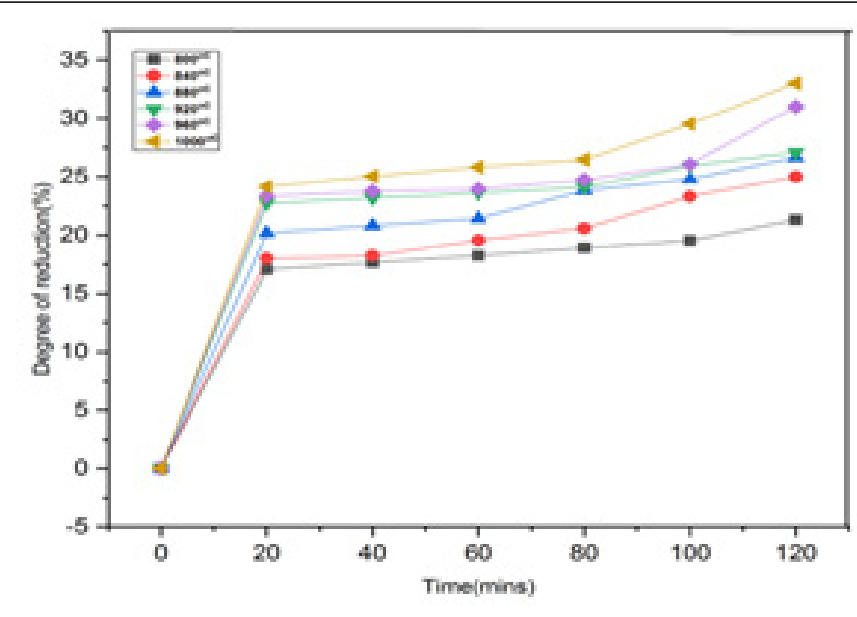

Figure 17: Degree of reduction (\%) of Agbaja iron ore lumps versus time (in mins) at temperature between $800{ }^{\circ} \mathrm{C}$ to $1000{ }^{\circ} \mathrm{C}$.

\section{Discussion}

The investigation on the reducibility study on Agbaja iron ore lumps: In this study, reducibility behaviour of Agbaja iron ores lumps (size: $20 \mathrm{~mm}$ approximately) was determined. The Iron ore for $20 \mathrm{mins}$.
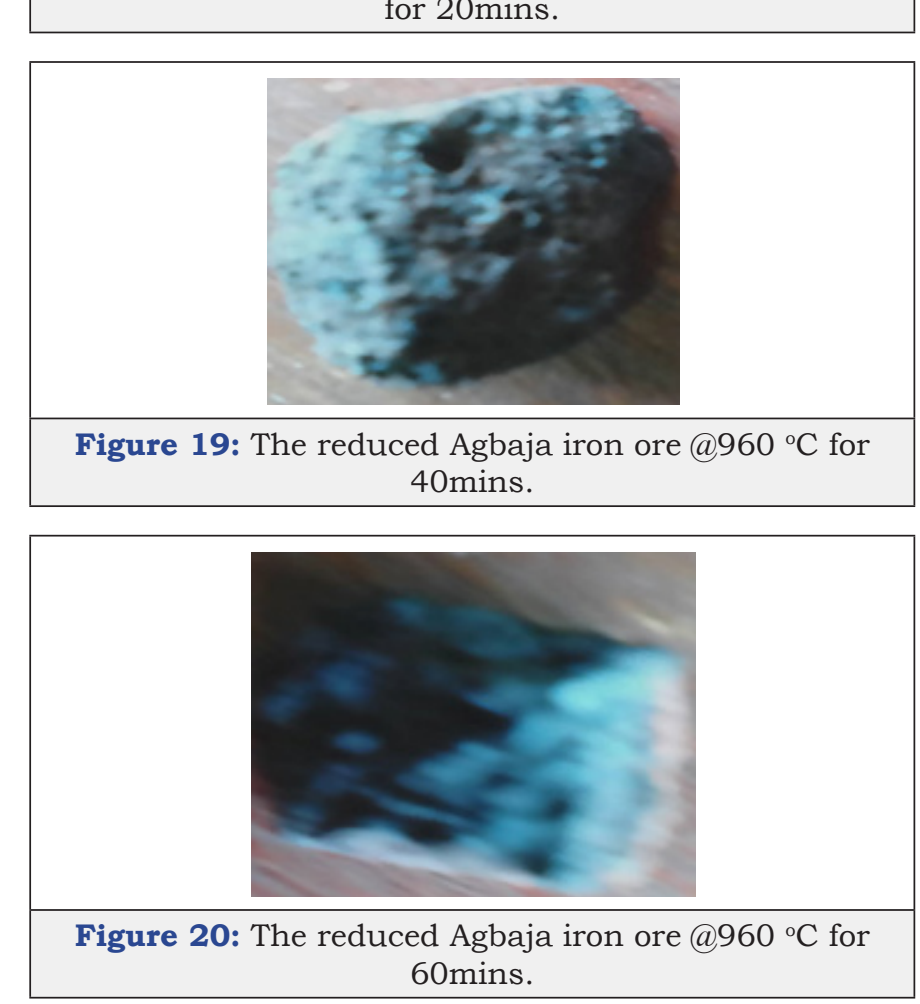


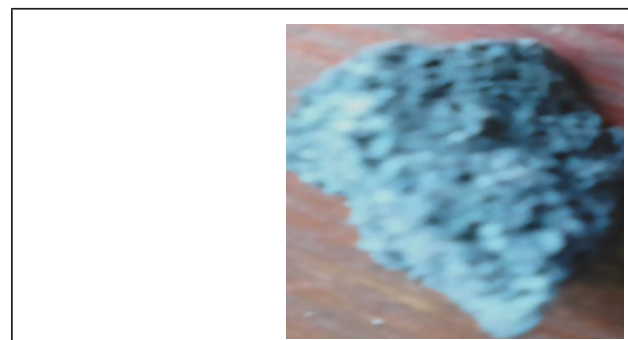

Figure 21: The reduced Agbaja iron ore $@ 960{ }^{\circ} \mathrm{C}$ for 80mins.
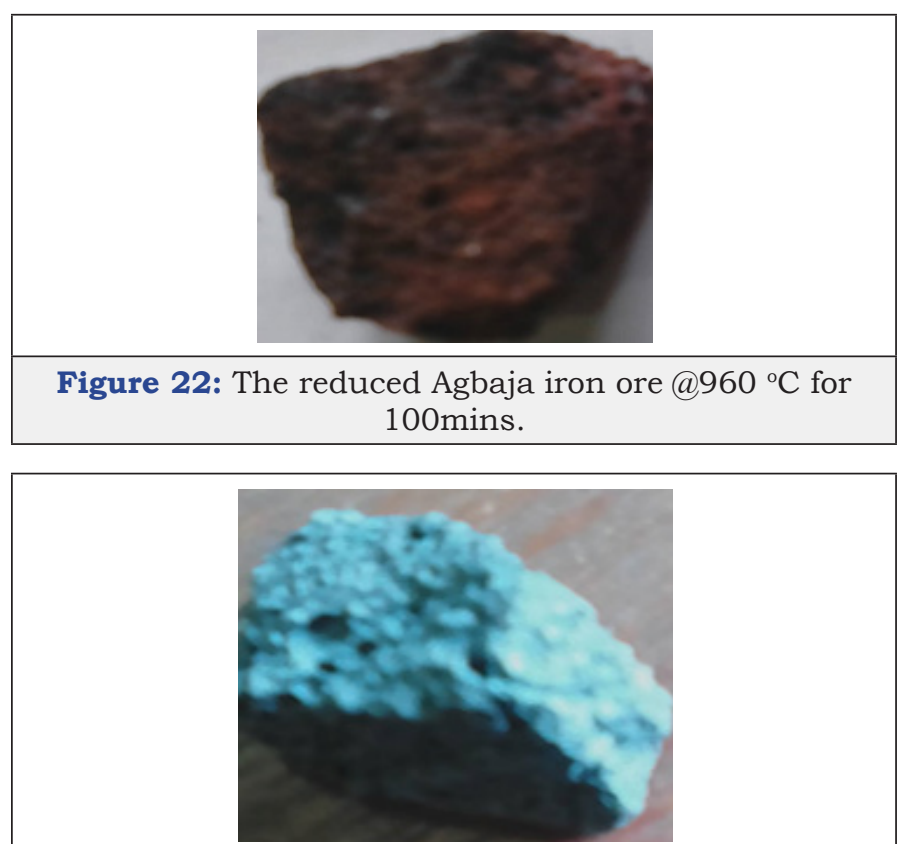

Figure 23: The reduced Agbaja iron ore $@ 960{ }^{\circ} \mathrm{C}$ for 120 mins.

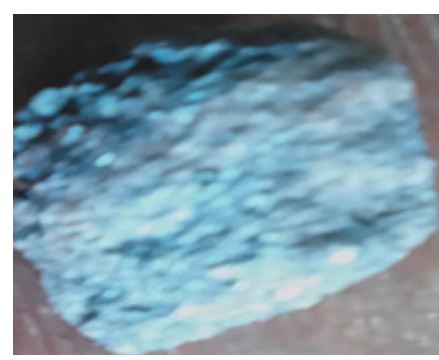

Figure 24: The reduced Agbaja iron ore @ $1000{ }^{\circ} \mathrm{C}$ for 20mins.

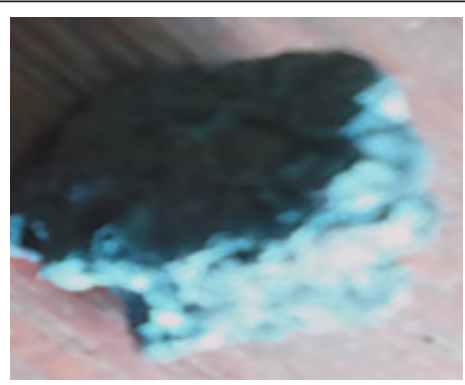

Figure 25: The reduced Agbaja iron ore @ $1000{ }^{\circ} \mathrm{C}$ for 40mins.

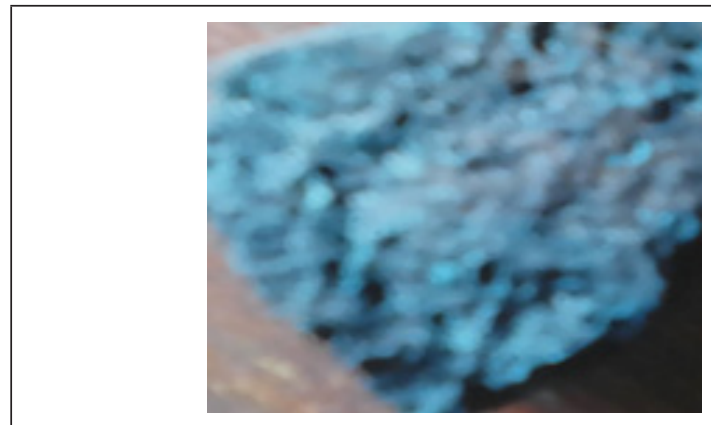

Figure 26: The reduced Agbaja iron ore $@ 1000{ }^{\circ} \mathrm{C}$ for 60 mins.
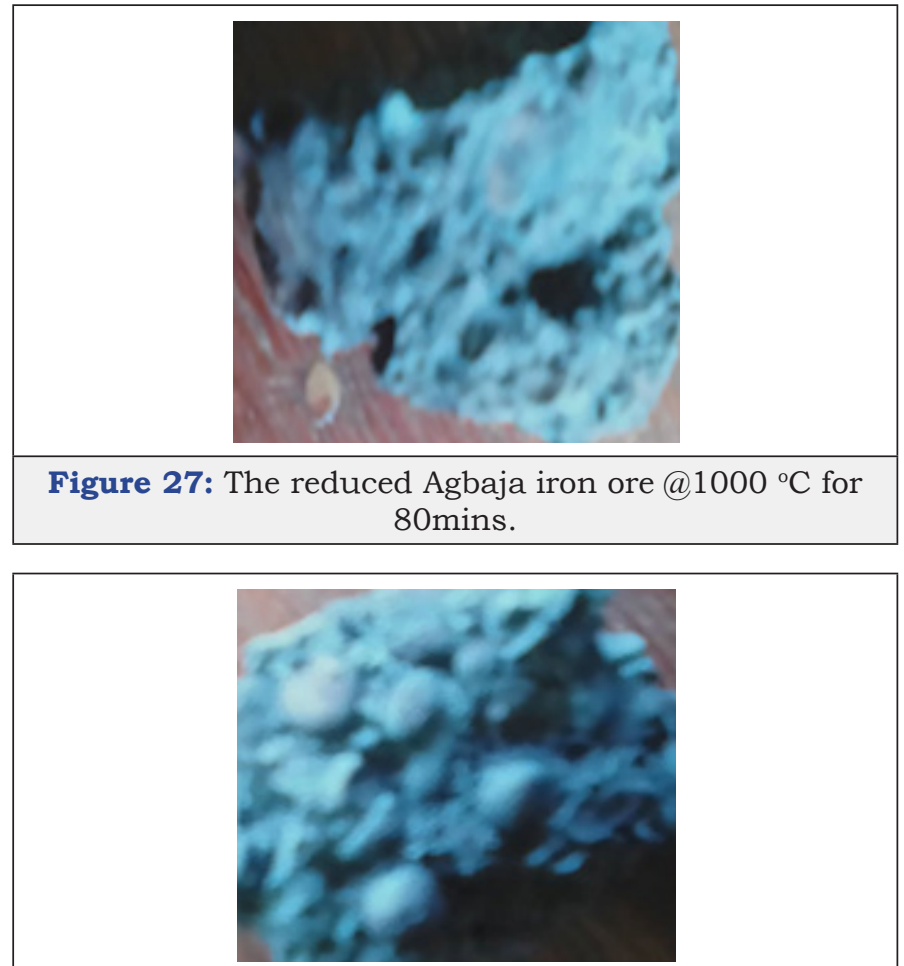

Figure 28: The reduced Agbaja iron ore @ $1000{ }^{\circ} \mathrm{C}$ for 100 mins.

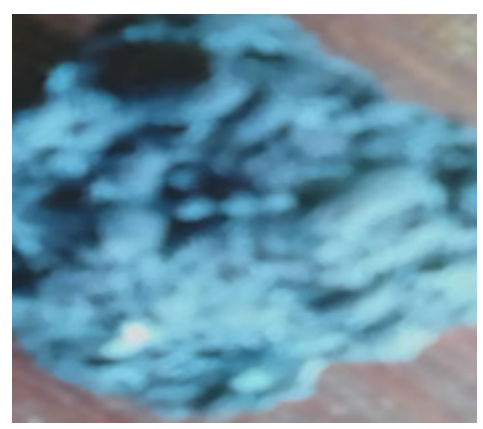

Figure 29: The reduced Agbaja iron ore $@ 1000$ C for 120 mins.

Effect of time on degree of reduction: The experiments performed in the research work show that rapid heating of the Agbaja iron ore lumps have significant effects on the heating time. The results of these effects are shown in Table 5 which indicated the highest degree of reduction (\%). 
It was also observed that the Agbaja iron ore completely reduced (more than $90 \%$ reduction) in about 120 minutes. The excessively high degree of reduction in the first 40 minutes was mainly associated with the release of volatiles from the metallurgical coking coal used due to their reformation into $\mathrm{H}_{2}$, $\mathrm{CO}$, etc.

The major participation of these reducing gases in the reduction of iron oxide (i.e. an appreciable presence of $\mathrm{H}_{2}$ and $\mathrm{CO}$ in the reduction chamber gives a boost in the reduction rate). The decrease in reduction rate with increasing time above 60 minutes was undoubtedly due to the combined effects of an increase in product metallic layer thickness and diminished evolution of volatile matter from the coal. An increase in the thickness of produced iron layer offers greater resistance in the diffusion of carbon and reducing gas to the surface of unreduced iron oxide.

The effect of heating mode on the samples were studied with a view to determining its effects on the degree of reduction (\%) in iron ore lumps. The Agbaja iron ore lumps were reduced using metallurgical coking coal at temperature range between $800^{\circ} \mathrm{C}-1000^{\circ} \mathrm{C}$ ( the soaking times were varied from 20 minutes -120 minutes at an interval of $20 \mathrm{~min}$ ), these experiments were performed under rapid and slow heating conditions with the use of muffle furnace. It was more likely that rapid heating from 920 ${ }^{\circ} \mathrm{C}$ to $1000^{\circ} \mathrm{C}$ causes higher rate of volatile matter escaping from the metallurgical coking coal, thereby providing less time for $\mathrm{H}_{2}$ and $\mathrm{CO}$ (reducing gases) to be in contact with the iron ore lumps.

The results in this research work thus indicate that there were some level of the degree of reduction in rapid heating in the iron ore lumps during lower heating operation. The volatile matters were released from coal at a slower rate. The more deposition of highly reactive pyrolytic carbon and increased time of contact of carbon and reducing gases $\left(\mathrm{H}_{2}\right.$ and $\left.\mathrm{CO}\right)$ with the iron ore lump appearing to be the obvious reasons for the high degree of reduction (\%).

\section{Effect of heating mode on the degree of reduction (\%)}

Scanning Electron Microscopy (SEM) of the Agbaja iron ore: (reducibility of Agbaja iron ore lumps at $800{ }^{\circ} \mathrm{C}, 920{ }^{\circ} \mathrm{C}$ and $1000^{\circ} \mathrm{C}$ )

Agbaja Iron Ore @ $800{ }^{\circ} \mathrm{C}$ for 120 minutes @920 ${ }^{\circ} \mathrm{C}$ for 120 minutes and @ $1000{ }^{\circ} \mathrm{C}$ for 120 minutes after the reducibility tests: Examination by using the Scanning Electron Microscopy (SEM) showing the morphologies of structures at $100 \mu \mathrm{m}$ (Figure 30-32).

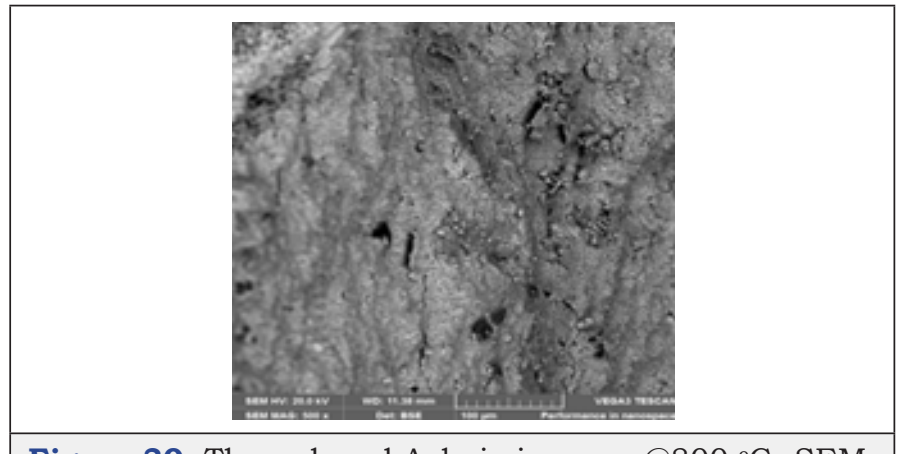

Figure 30: The reduced Agbaja iron ore $@ 800{ }^{\circ} \mathrm{C}$-SEM.

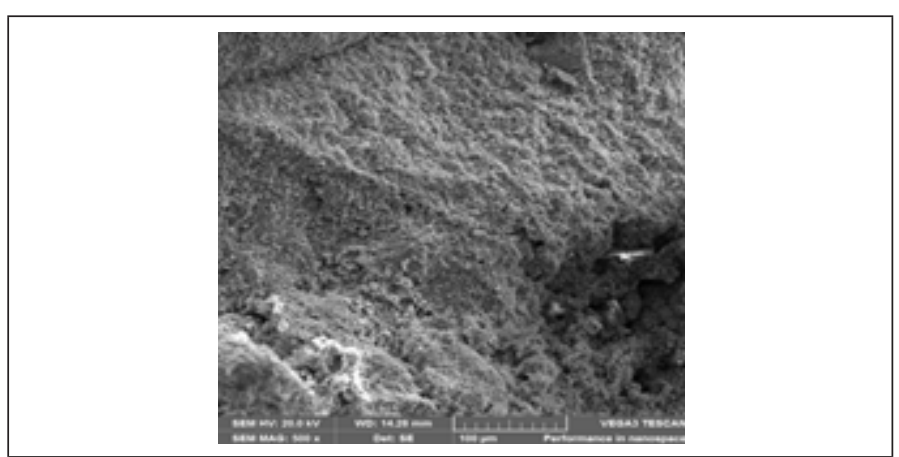

Figure 31: The reduced Agbaja iron ore @ $920{ }^{\circ} \mathrm{C}-\mathrm{SEM}$.

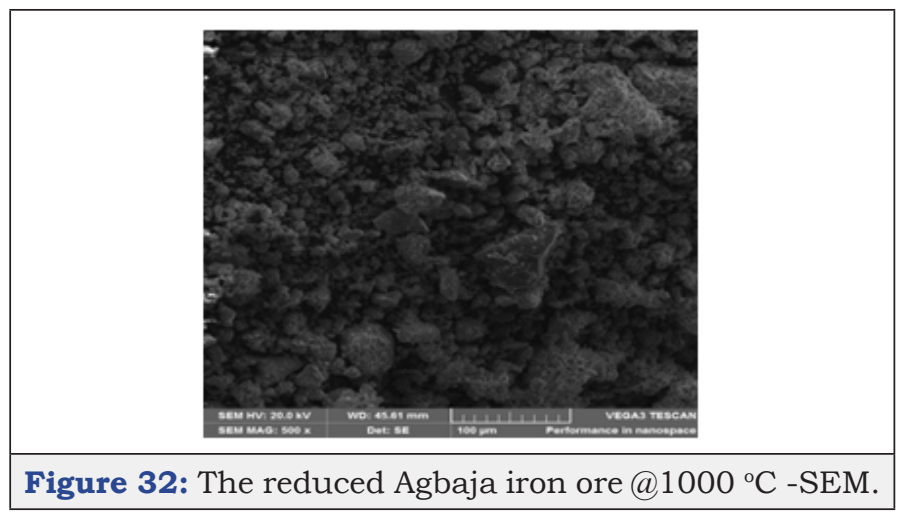

Energy-Dispersive Spectroscopy (EDS) Agbaja iron ore after reducibility tests on samples at $800^{\circ} \mathrm{C}$ for 120 minutes, @920 $\mathrm{C}$ for 120 minutes and $@ 1000^{\circ} \mathrm{C}$ for 120 minutes

Figure 33a \& 33b show the EDS of Agbaja iron ore $@ 800^{\circ} \mathrm{C}$ for after reducibility test on electron image 4 and the EDS where the concentration of the elements are distributed with weight (\%) concentration ranging from $\mathrm{O}, \mathrm{Fe}, \mathrm{C}, \mathrm{Al}, \mathrm{Si}$ and $\mathrm{P}$ and also with their corresponding density values.

Figure 33(a) \& (b): Electron image 4 and the EDS where the concentration of the elements were distributed of Agbaja iron ore $@ 800{ }^{\circ} \mathrm{C}$ after reducibility test. 

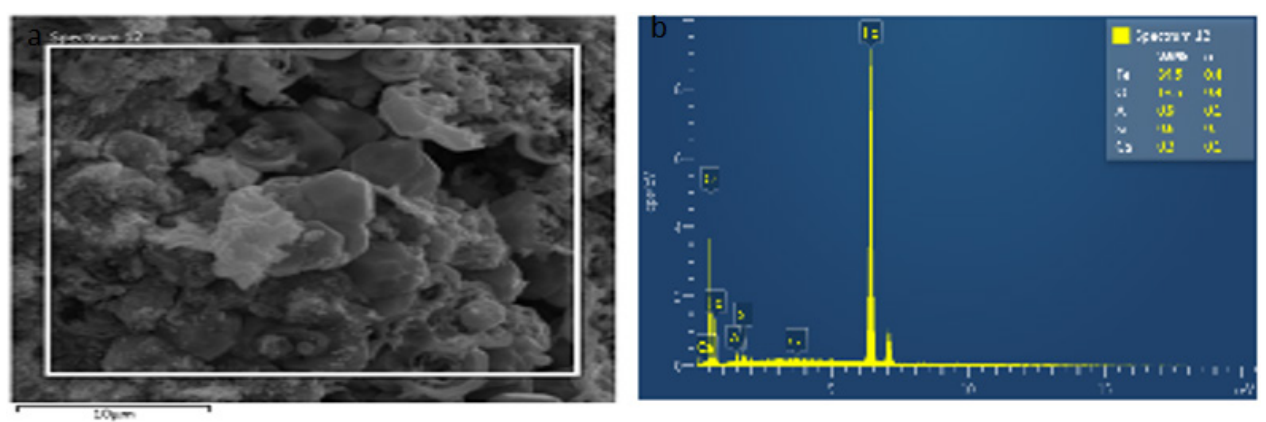

Figure 34(a) \& (b): Electron image 4 and the EDS where the concentration of the elements were distributed of Agbaja iron ore $@ 800{ }^{\circ} \mathrm{C}$ after reducibility test.

Figure 34a \& 34b show the EDS of Agbaja iron ore @ $920^{\circ} \mathrm{C}$ for 120 minutes after reducibility test on electron image 7 and the EDS where the concentration of the elements are distributed with weight (\%) concentration ranging from $\mathrm{Fe}, \mathrm{O}, \mathrm{Al} \mathrm{Si}$ and $\mathrm{Ca}$ also with their corresponding density values.
Figure 35a \& 35b show the EDS of Agbaja iron ore @ $1000^{\circ} \mathrm{C}$ for 120 minutes after reducibility test on electron image 9 and the EDS where the concentration of the elements are distributed with weight (\%) concentration ranging from $\mathrm{Fe}, \mathrm{O}, \mathrm{Ti}, \mathrm{Al}, \mathrm{Si}, \mathrm{Ba}, \mathrm{Mn}$ and $\mathrm{P}$ also with their corresponding density values.
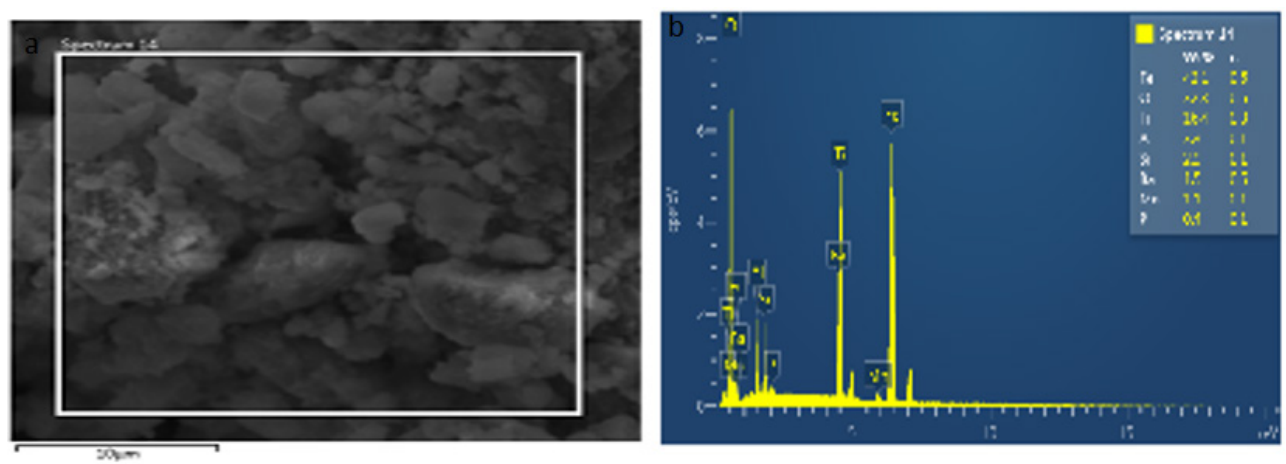

Figure 35(a) \& (b): Electron image 11 and the EDS where the concentration of the elements were distributed of Agbaja iron ore $@ 1000{ }^{\circ} \mathrm{C}$ after reducibility test.

Summary of the analysis on results after the reducibility test (SEM and EDS) findings and contribution to knowledge

Table 6 shows analysis of the results of samples after performing the reducibility Tests using SEM and EDS on Agbaja Iron Ore at 800 ${ }^{\circ} \mathrm{C}$ for 120 minutes, at $920^{\circ} \mathrm{C}$ for 120 minutes and at $1000^{\circ} \mathrm{C}$ for 120 minutes. The processes indicated that at $800^{\circ} \mathrm{C}$ for 120 minutes the Fe content obtained was $90.2 \mathrm{wt} \%$. As the ores were heated to 920 ${ }^{\circ} \mathrm{C}$ for 120 minutes a value of Fe content obtained was $84.5 \mathrm{wt} \%$. The samples were further subjected to reducibility test at $1000^{\circ} \mathrm{C}$ for 120 mins and the value Fe content obtained was $42.1 \mathrm{wt} \%$.

Table 6: Analysis of results of samples after performing the reducibility tests using SEM and EDS on Agbaja iron ore.

\begin{tabular}{|c|c|c|c|c|c|c|c|c|c|}
\hline S/No & Sample Name & $\begin{array}{c}\text { Temperature } \\
\text { in Degree }\end{array}$ & Fe (Wt \%) & C (Wt\%) & Ca (Wt\%) & $\mathbf{0}_{\mathbf{2}}$ (Wt\%) & Al (Wt\%) & Zn (Wt\%) & Si (Wt\%) \\
\hline 1 & Agbaja Iron Ore & $800^{\circ} \mathrm{C}$ & 90.2 & 5.6 & 0 & 1.9 & 1.1 & 1.0 & 0.2 \\
\hline 2 & Agbaja Iron Ore & $920^{\circ} \mathrm{C}$ & 84.5 & 0 & 0.3 & 13.6 & 0.9 & 0 & 0.6 \\
\hline 3 & Agbaja Iron ore & $1000^{\circ} \mathrm{C}$ & 42.1 & 0 & 0 & 32.3 & 3.3 & 0 & 2.9 \\
\hline
\end{tabular}

\section{Findings and contribution to knowledge}

The Agbaja iron ore has been known to have large deposits in Kogi State of Nigeria. In the past, the government of Nigeria have been involved in the importation of high-grade ores. It must be noted that the processes of importation and financial constraints and cost implication which in the past has run into over 607 dollar/ tonne even when the plants were not operated at the optimal capacity.
The investigation on the reducibility on the Agbaja Iron ore was performed, and the contributions to knowledge from this research work may be viewed in these ways:

a) That the project was successfully completed and the data generated should serve as data bank which could further translate to generating valid information for further study on similar or other iron ore that are available in the country. 
b) That the relevant data could assist the would be researchers in this field of study which has created ample opportunity of the needed knowledge on the best methods and necessary reducibility studies.

c) That the experimental techniques explored revealed the mineralogy, morphologies of the ores and the reducibility processes.

\section{Conclusion}

The investigation on the reducibility on the Agbaja iron ore lumps was intensively studied. The study performed revealed the followings:

a) The time of reduction and temperature of the iron ore lumps of Agbaja indicates that there was greater influence on the degree of reduction (\%). It was observed that the degree of reduction (\%) increased with increase in heating time from $800{ }^{\circ} \mathrm{C}-1000$ ${ }^{\circ} \mathrm{C}$. The time for the degree of reduction was performed within the time range of $20-120$ minutes (20 minutes intervals) as these processes indict that the degree of reduction (\%).

b) The reduction behavior of the iron ore lumps are identical in all the investigation. The use of the metallurgical coking coal as reducing agent had great effects on the lumps as there were significant influences on the degree of reduction (\%) on the tested samples.

c) From the findings of the investigation, the results and data obtained could be used for further studies while the other iron ore deposits in the country could also be subjected to other experimental investigations and processes. Such ores could also be investigated and subjected to the reducibility studies, with other iron ores with a view to generating the necessary data and to make comparism with those already investigated.

\section{Recommendations for Future Research}

a) Enough funds will be needed to perform this kind of research work because of its capital involvement nature which is intensive. In regards to this, some of the research institutions, universities and Industries where such research works are performed should have rates that could be greatly affordable to students, researchers. In some cases waivers could also be granted to reduce costs.

b) Time should be made available for the completion of this kind of research work within the academic period as many experimental procedures and processes are involved.

c) Sourcing of the raw iron ores from the National Metallurgical Development Centre (NMDC), Jos, National Iron ore Mining Company (NIOMCO), Itakpe and Agbaja plateau in Kogi State posed some challenges.

d) The accessibility to source for these materials were very difficult as lot of resources and money were spent to obtain the materials and also the security network of the locations and terrain were not easily accessible.Efforts should therefore be made by all the stake holders to always assist researchers, students and other individuals by creating enabling environments and opportunities to have access to these raw materials.

e) As regards the equipment used in performing these experiments, some of them were not readily available in Nigeria like Scanning Electron Microscopy (SEM) with EDS, the Thermogravimetric Analysis (TA) and the Differential Thermal Analysis (DTA), the X-Ray Fluorescence (XRF), R-Xay Diffraction (XRD) and other facilities. These issues posed a lot of challenges as the samples were sent to South Africa and waited for the results to be sent back and the money involved in performing such tests. In most cases, where such equipment are available in Nigeria, they are bedeviled with issues ranging from faulty parts, total breakdown, in accuracy, doubts results and non compliance to international standard or global best practice.

f) The cost of performing such experiments are relatively high for an average students / researchers to afford, therefore, Governments and other research Institutes, Universities and Industries should reduce the cost of performing such experiments with a view to encouraging researchers .

g) In view of the above therefore, the Universities, Research Institutes in Nigeria should collaborate with agencies like the NLNG, TETFUNDS, PTDF, and SHELL CHEVRON, AGIP e. t. c to supply such equipment and to collaborate with students/ researchers in order to achieve optimal results.

h) The research work performed is not exhaustive as more work could be experimented with other iron ores available within Kogi State like the Agbajanoko, Oshokosho, Konto Karfi, BassaNge and Muro and in other States in Nigeria.

Finally, there should be synergy between Government, Universities, Research Institutes and industries with a view to solving basic problems in extractive and process metallurgy through collaborations.

\section{References}

1. BRG report (1983) Survey, Research and test of Agbaja, Lokoja, KotonKarfe and Bassange iron ore deposits, final report.

2. Adedeji FA, Sale FR (1984) Characterization and Reducibility of Itakpe and Agbaja (Nigerian) Iron ores. Delta Steel Complex Warri, Nigeria and Department of Metallurgy and Materials Science, University of Manchester Grosvenor Street, England, pp. 843-856.

3. Mohammed RA, Dada ET, Hassan SB, Abdulwahab M (2014) Assessment of mechanical properties of pellets produced from Itakpe/Agbaja iron ore blends. A paper published in the Nigerian Metallurgical Proceeding at the $30^{\text {th }}$ Annual Conference and Annual General Meeting of the Nigerian Metallurgical Society at the Raw Materials Research and Development Council Abuja paper. 